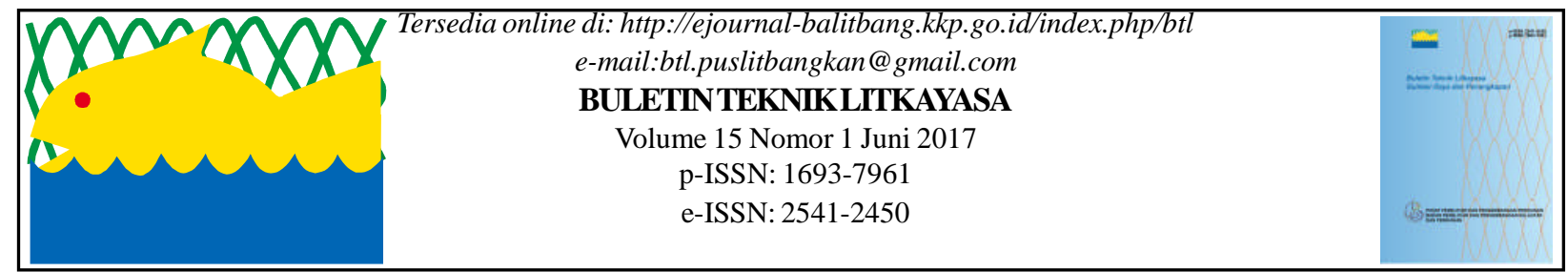

\title{
TEKNIK PENGAMATAN FEKUNDITAS DAN DIAMETER TELUR LOBSTER PASIR (Panulirus homarus) DI PERAIRAN PESISIR PANGANDARAN, JAWA BARAT
}

\author{
Henra Kuslani dan Sumindar \\ Teknisi Litkayasa Balai Penelitian Pemulihan dan Konservasi Sumber Daya Ikan \\ Teregistrasi I tanggal: 06 Maret 2017; Diterima setelah perbaikan tanggal: 08 Juni 2017; \\ Disetujui terbit tanggal: 13 Juni 2017
}

\section{PENDAHULUAN}

Lobster pasir atau (Panulirus homarus) merupakan salah satu jenis lobster yang memiliki nilai ekonomis penting dan banyak ditangkap di perairan Indonesia, salah satunya di sekitar perairan pesisir Pangandaran, Jawa Barat. Menurut Aisyah et al., (2009) dua jenis lobster dominan di perairan Selatan Jawa yakni lobster pasir dan lobster batu.

Reproduksi lobster diawali dengan bercampurnya spermatozoid lobster jantan dengan telur (ovum) betina sehingga menghasilkan telur yang dibuahi. Pembuahan lobster marga Panulirus terjadi diluar, kemudian telur-telur yang telah dibuahi diletakkan di bawah perut lobster betina, melekat pada bulu-bulu yang terdapat pada umbai-umbai kaki renang (Romimohtarto dan Juwana, 2007). Pembuahan terjadi setelah telur-telur dikeluarkan dan ditarik kearah abdomen yaitu dengan cara merobek selaput pembungkus oleh betina dengan menggunakan cakar (kuku) yang berupa capit terdapat pada ujung pasangan kaki jalannya. Lobster yang sedang bertelur melindungi telurnya dengan cara meletakkan atau menempelkan dibagian bawah dada (abdomen) sampai telur tersebut dibuahi dan menetas menjadi larva atau biasa disebut burayak atau tumpayak (Moosa dan Aswandy, 1984). Menurut Prisdiminggo (2002), lobster mempunyai periode pemijahan yang panjang puncaknya pada bulan November sampai Desember. Setiap individu hanya sekali memijah setahun. Tetapi pada musim perkembangbiakan, lobster dapat melakukannya lebih dari satu kali pemijahan. Waktu pemijahan sangat berhubungan dengan temperatur.

Tujuan penelitian untuk mengetahui fekunditas dan sebaran diameter telur lobster pasir (Panulirus homarus) sebagai salah dasar pengelolaan lobster pasir di perairan pesisir Pangandaran Jawa Barat.

\section{POKOK BAHASAN \\ Lokasi dan Waktu Penelitian}

Lokasi penangkapan lobster oleh nelayan, di perairan pesisir Pangandaran pada bulan November, 2015 di sekitar perairan pesisir Pangandaran, Jawa Barat. Jumlah sampel lobster pasir (Panulirus homarus) betina didapat sebanyak 8 ekor pada sebaran tingkat kematangan gonad III, IV dan gonad yang sudah dibuahi

\section{Bahan dan Alat}

Bahan dan alat yang digunakan dalam teknik pengamatan fekunditas dan diameter telura dapat dilihat pada Tabel 1.

\section{Metode}

Lobster hasil tangkapan nelayan diukur panjang karapasnya menggunakan kaliper yaitu dari tepi post orbital sampai ujung posterial karapasnya. Pengukuran panjang karapas dilakukan dengan cara mengukur panjang dari tepi post orbital sampai ujung posterior karapasnya, sesuai petunjuk Sparre and Venema (1992). (Gambar 1). 
Tabel 1. Bahan dan Alat yang digunakan

\begin{tabular}{|c|c|}
\hline Bahan dan Alat & Keterangan \\
\hline \multicolumn{2}{|l|}{ Bahan : } \\
\hline - Formalin $5 \%$ & Pengawet sampel telur lobster \\
\hline - Lobster Pasir & Sampel yang diamati \\
\hline \multicolumn{2}{|l|}{ Alat: } \\
\hline - Kalifer & Alat pengukur panjang karapas lobster \\
\hline - $\quad$ Timbangan digital (ketelitian 0,01 gram) & Menimbang bobot lobster \\
\hline - $\quad$ Gunting & \\
\hline & Membedah lobster \\
\hline Plastik sampel & Menyimpan sampel lobster \\
\hline Kertas kalkir & Label sampel lobster \\
\hline - Kamera digital & Dokumentasi sampel lobster \\
\hline - $\quad$ Alat tulis menulis & Alat pencatatan data \\
\hline - Blanko pengamatan & Mencatat hasil pengukuran telur \\
\hline - Botol sampel & Wadah menyimpan sampel telur \\
\hline - $\quad$ Mikroskop binokuler & Mengamati butiran telur \\
\hline - Mikrometer & Mengukur diameter telur \\
\hline - Counter & Menghitung butiran telur \\
\hline
\end{tabular}

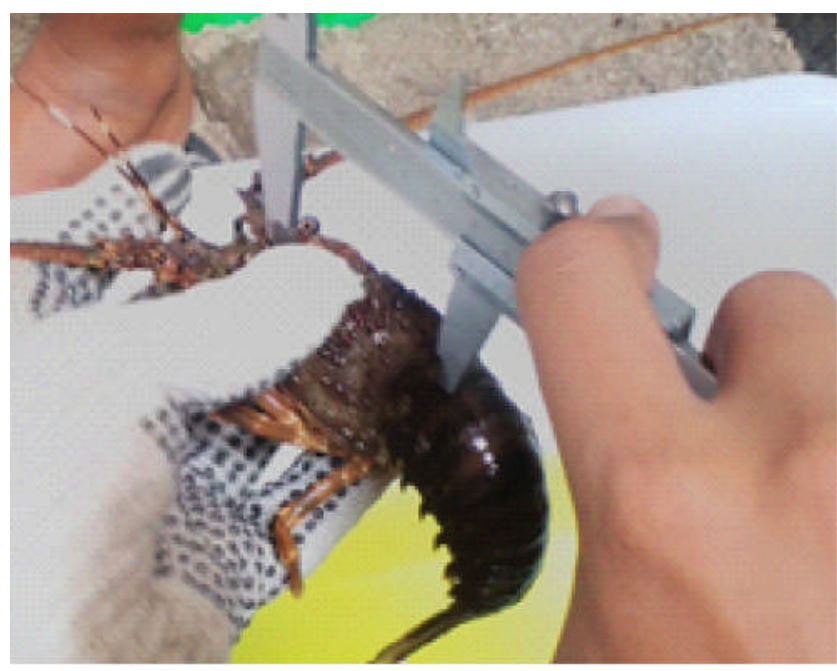

Gambar 1. Pengukuran panjang karapas lobster.

1. Pengukuran bobot lobster menggunakan timbangan digital ketelitian $(0,01)$ gram. (Gambar 2$)$.

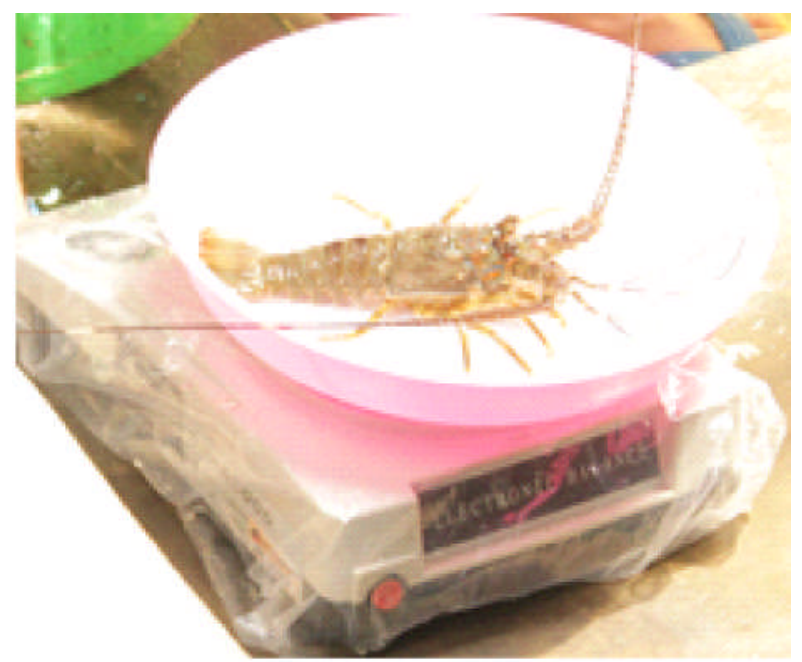

Gambar 2. Pengukuran bobot lobster 
2. Sampel lobster dibedah atau digunting untuk diambil telurnya yang terletak pada kepala dengan menggunting persegi pada karapasnya agar sampel terlihat dan mudah diambilnya Pengambilan telur lobster menggunakan pinset secara perlahan-lahan dan hati-hati agar sampel telur diambil dalam keadaan baik dan tidak rusak. Disajikan pada (Gambar 3a). Bentuk telur lobster berbentuk seperti hurup $\mathrm{H}$ seperti pada (Gambar

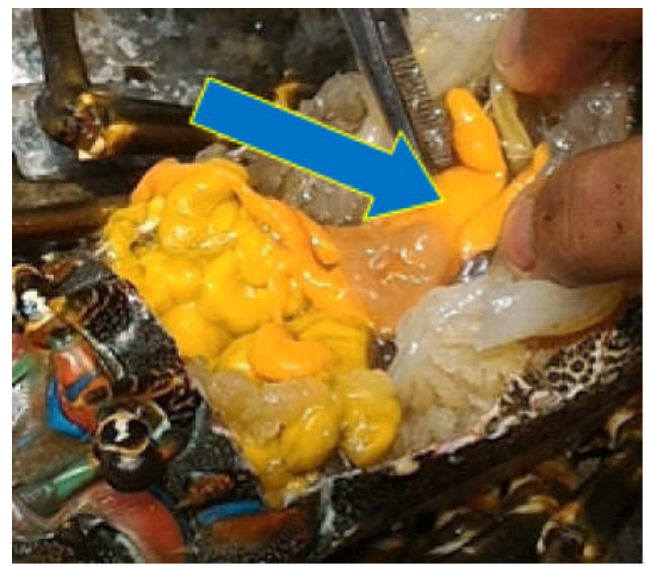

Gambar 3a. Telur lobster

\section{Pengamatan telur lobster di Laboratorium.}

1. Sampel dibuka dan diletakkan pada petridish serta diberi air mengalir untuk mengurangi larutan formalinnya. (Gambar 4).

2. Kemudian sampel dikering-anginkan agar berat air pada telur tidak mempengaruhi berat telurnya.

3. Bobot telur ditimbang sebagai berat telur keseluruhan menggunakan timbangan digital ketelitian (0.001 gram).

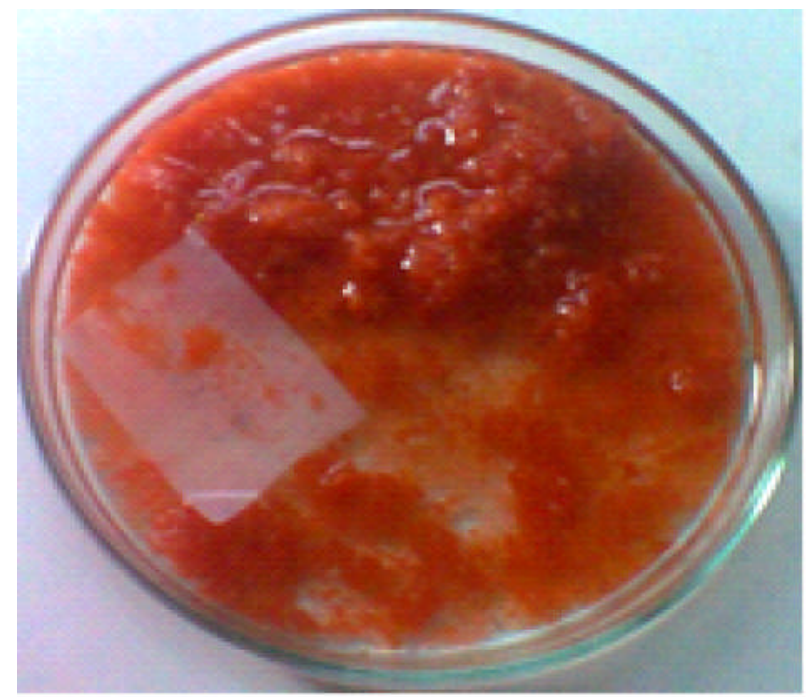

Gambar 4. Sampel telur lobster dalam petridish 3b). Sebaiknya pengambilan sampel telur lobster yaitu ketika lobster masih segar.

3. Sampel telur dimasukan kedalam plastik dan ditambahkan larutan formalin $5 \%$ agar sampel awet dan tidak rusak (Effendie, 1979). Kemudian sampel dimasukkan kedalam cool box untuk diamati di Laboratorium BP2KSI (Balai Penelitian Pemulihan dan Konservasi Sumber Daya Ikan).

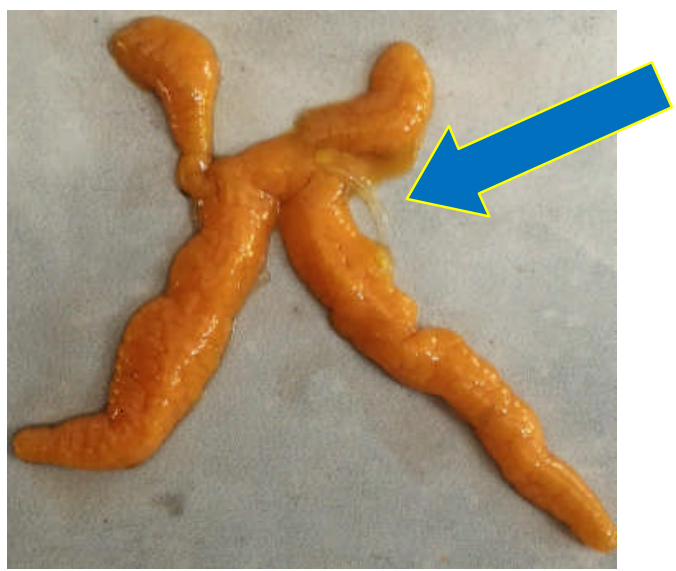

Gambar 3b. Bentuk Telur lobster seperti huruf $\mathrm{H}$.

4. Telur diambil sebagian kemudian ditimbang kembali sebagai berat sub sampel telur yang akan diukur diameternya. Pengukuran diameter telur menggunakan mikroskop binokuler pada pembesaran 40 kali (lensa okuler 10x dan 4x lensa objektif) serta memasukan micrometer didalamnya sebagai alat ukur diameter. Perhitungan pada pembagian 100 skala dan hasil persatuan skala 0,025 milimikron, lalu dihitung jumlah semua telur dengan menggunakan counter. Disajikan pada Gambar 5.

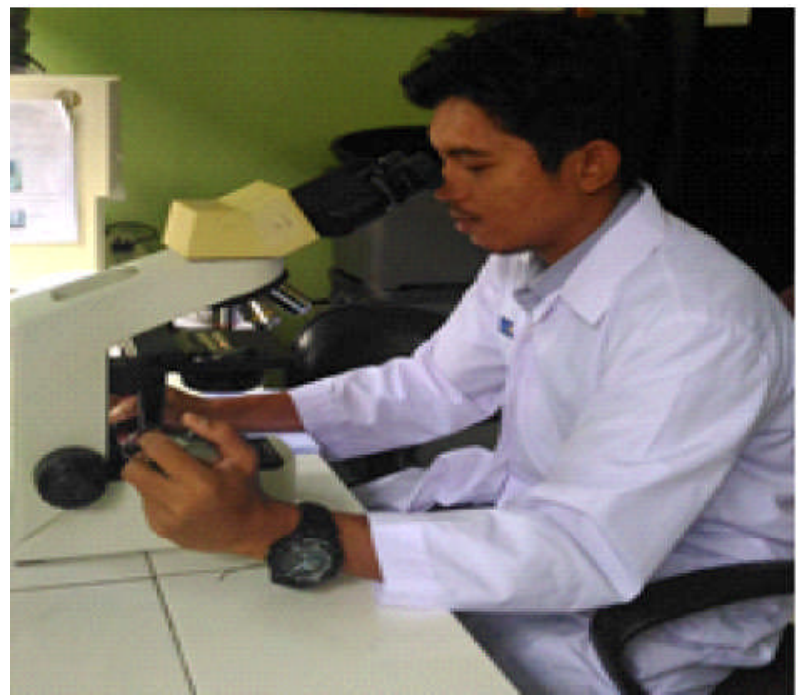

Gambar 5. Pengamatan diameter telur lobster. 
5. Fekunditas total atau mutlak didefinisikan sebagai jumlah telur yang terdapat dalam ovari ikan/udang betina yang sudah matang (mature) (Nikolsky, 1963), ditentukan menggunakan gabungan dari metode gravimetrik dan metode sub contoh (Effendie, 1979) dengan rumus:

Keterangan:

$$
F=\frac{G}{Q} X
$$

$\mathrm{F}=$ Fekunditas (butir)

$X=$ Jumlah telur dalam sebagian kecil dari sampel gonad (butir)

$\mathrm{G}=$ Berat seluruh sampel gonad (gram)

$Q=$ Berat sebagian kecil dari sampel sampel gonad (gram)

\section{Hasil}

Hasil pengamatan dan pengukuran diameter telur lobster yang tertangkap sebanyak 8 ekor lobster pasir betina dengan tingkat kematangan telur III, IV dan ada 1 ekor telur yang sudah dibuahi yaitu telur yang sudah berada di luar perut, menempel pada kaki-kaki renang lobster tersebut. Panjang karapas lobster berkisar antara 5,9-6,9 cm dengan bobot 206,08309,45 gram.

Telur lobster pada tingkat kematangan III memiliki sebaran diameter berkisar $0,10-0,25 \mathrm{~mm}$ dengan fekunditas berjumlah $31.269-142.971$ butir pada bobot berkisar antara 215, 98 - 305,08 gram. Pada tingkat kematangan IV memiliki sebaran diameter 0,23 $-0,50 \mathrm{~mm}$ dengan jumlah fekunditas sebanyak $107.563-150.459$ butir pada bobot berkisar 273,67 $-309,45$ gram. Sedangkan telur yang sudah dibuahi 1 ekor dengan panjang karapas $6,9 \mathrm{~cm}$ dan bobot 309,45 gram memiliki sebaran diameter telur antara $0,43-0,73$ $\mathrm{mm}$ dengan jumlah fekunditas sebanyak 3.254 butir.

Jumlah telur yang sudah dibuahi dan dibawa induk lobster didapat lebih sedikit dari pada fekunditasnya. Hal tersebut disebabkan beberapa kemungkinan. Kemungkinan pertama jumlah telur yang menempel pada kaki-kaki renang lobster sudah sebagian terlepas akibat penangkapan lobster tersebut. Kemungkinan kedua, induk lobster tersebut hanya mampu membawa telur yang sudah dibuahi kurang dari 5\% dari fekunditas telurnya. Disajikan pada Tabel 2.

Tabel 2. Fekunditas dan sebaran diameter telur lobster pasir :

\begin{tabular}{lcccccccc}
\hline No & $\begin{array}{c}\text { Panjang } \\
\text { karapas } \\
\text { (cm) }\end{array}$ & $\begin{array}{c}\text { Bobot } \\
\text { (gram) }\end{array}$ & $\begin{array}{c}\text { Bobot } \\
\text { total } \\
\text { telur } \\
\text { (gam) }\end{array}$ & $\begin{array}{c}\text { Bobot } \\
\text { sub } \\
\text { sampe } \\
\text { I } \\
\text { (gram) }\end{array}$ & $\begin{array}{c}\text { Jumlah } \\
\text { butir }\end{array}$ & TKG & $\begin{array}{c}\text { Fekunditas } \\
\text { (butir) }\end{array}$ & $\begin{array}{c}\text { Diameter } \\
\text { telur (mm) }\end{array}$ \\
\hline 1 & 5,9 & 215,98 & 2.123 & 0,229 & 10940 & III & 101.422 & $0.15-0.33$ \\
2 & 6,1 & 223,75 & 1.141 & 0,200 & 5481 & III & 32.269 & $0.13-0.30$ \\
3 & 6,1 & 249,70 & 2,633 & 0,237 & 12869 & III & 142.971 & $0.20-0.40$ \\
4 & 6,2 & 206,08 & 0.292 & 0.078 & 9513 & III & 35.613 & $0.10-0.25$ \\
5 & 6,6 & 305,08 & 2,630 & 0,212 & 8829 & III & 109.530 & $0.13-0.38$ \\
6 & 6,3 & 273,67 & 6,280 & 0,391 & 6697 & IV & 107.563 & $0.25-0.50$ \\
7 & 6,4 & 273,67 & 6,383 & 0,439 & 10348 & IV & 150.459 & $0.25-0.48$ \\
8 & 6,9 & 309,45 & 9,183 & 0,824 & 12996 & IV & 144.833 & $0.23-0.48$ \\
9 & 6,9 & 309,45 & 2,373 & 2,373 & 3254 & - & 3.254 & $0.43-0.73$ \\
\hline
\end{tabular}

Keterangan : Yang bertanda (-) yaitu telur lobster sudah dibuahi.

Pengamatan fekunditas lobster pasir juga dilakukan oleh (Junaidi, et al. 2010), menyatakan bahwa hasil pendugaan fekunditas lobster pasir berkisar antara 28.000 - 96.000 butir pada kisaran panjang karapas antara $80-95 \mathrm{~mm}$. Sementara
Moosa dan Aswandy (1984), jumlah telur lobster jenis yang sama mencapai $50.000-80.000$ butir, tergantung pada ukuran bobot lobster. Menurut Andy Omar (2005), fekunditas pada suatu species ikan dapat berbeda antara satu individu dengan individu 
lainnya. Hasil pengamatan jumlah fekunditas lobster pasir di perairan pesisir Pangandaran Kabupaten Pangandaran tidak jauh berbeda jumlahnya dengan pengamatan yang sudah dilakukan yaitu berkisar antara $32.269-150.459$ butir.

\section{KESIMPULAN}

Sebaran diameter telur lobster betina pada TKG III berkisar 0,10 - 0,25 $\mathrm{mm}$ dengan fekunditas berjumlah 32.269 - 142.971 butir. Pada TKG IV memiliki sebaran diameter 0,23-0,50 mm dengan fekunditas sebanyak 107.563 - 150.459 butir. Sedangkan telur yang sudah dibuahi memiliki sebaran diameter telur antara 0,43-0,73 $\mathrm{mm}$ dengan fekunditas sebanyak 3.254 butir.

\section{PERSANTUNAN}

Penulis mengucapkan terima kasih yang sebesarbesarnya kepada Prof. Dr. Ir. Endi Setiadi Kartamihardja, M.Sc, Dr. Fayakun Satria, S.Pi, M.App.Sc dan Danu Wijaya, S.Pi., M.Si sebagai Koordinator dan penanggung jawab kegiatan serta para peneliti yang telah membantu penulis sampai tulisan ini selesai. Data diperoleh dari penelitian Ecological Assessment untuk Restocking Benih Lobster di Kawasan Konservasi Perairan Indonesia 2015.

\section{DAFTAR PUSTAKA}

Aisyah, Badrudin, dan S. Triharyuni. 2009. Lobster Seed Resources in the South Coast of Yogyakarta. AARD. MMAF. (Unpubslihed Report, in Indonesian with English Abstract). 25 p.

Andy Omar, S. B. 2005. Aspek reproduksi cumi-cumi (Sepioteuthis lessoniana Lesson, 1830). Prosiding Seminar Nasional Tahun Hasil Penelitian Perikanan dan Kelautan Tahun 2005. UGM. Yogjakarta.

Chan, T.Y. 2000. Lobster. In the Living Marine Resources of the Western Center Pacific. Volume 2 Cephalopods, crustaceans, holothurians and sharks. FAO Species Identification Guide for Fishery Purposes. FAO-UN, Norwegian. Agency for International Development.

Effendie, M.I. 1979. Metode Biologi Perikanan, Yayasan Dewi Sri. Bogor. 112p.
FAO (Food Agriculture Organization). 2011-2012. Cultured Aquatic Species Information Programme. Panulirus homarus. Cultured Aquatic Species Information Programme. Text by Jones, C. In: FAO Fisheries and Aquaculture Department (Online). Rome. Update 16 September 2011. (Cited 9 October 2012). http://www.fao.org/fishery/ culturedspecies/Panulirus_homarus/en

Junaidi, M., Cokrowati, N., dan Abidin,Z. 2010. Aspek Reproduksi Lobster (Panulirus sp) di perairan Teluk Ekas Pulau Lombok. Jurnal Kelautan. 3 (1): 2936.

Moosa, M. K., dan Aswandy, I. 1984. Udang Karang (Panulirus spp) dari Perikanan Indonesia. LONLIPI. Jakarta. 38pp.

Nikolsky, G. V. 1963. The ecology of fishes. Transl. by L. Birkett. Academic Press. New York. 352 p.

Romimohtarto, K., dan S. Juwana. 2007. Biologi Laut IImu Pengetahuan tentang Biologi Laut. Edisi III. Penerbit Djambatan. Jakarta.

Sparre, P. and S.C. Venema. 1992. Introduction to tropical fish stock assessment. Part 1. Manual. FAO Fish. Tech. Pap., (306/1) Rev. 1: 376pp.

Tewfik A., D. Mills., dan Adhuri, D. 2009. Spiny lobster resources and opportunity for culture in posttsunami Aceh, Indonesia. In Williams K.C. (ed.) 2009. Spiny lobster aquaculture in the Asia-Pacific region. Proceedings of an international symposium held at Nha Trang, Vietnam, 9-10 December 2008. ACIAR Proceedings No. 132 (p.162). Australian Centre for International Agricultural Research: Canberra.

Yusnaini, M.N., Nessa, M. I. D., dan Trijuno, D.D. 2009. Ciri Morfologi Jenis Kelamin dan Kedewasaan Lobster Mutiara (Panulirus ornatus). Torani. Jurnal IImu Kelautan dan Perikanan. 19 (3): 166-174.

Prisdiminggo, Mashur, M. Nazam, L.,dan Wirajaswadi. 2002. Budidaya Ikan Kerapu Bebek (Cromileptes altivelis) dan Lobster (Panulirus sp) dalam Karamba Jaring Apung (KJA) di Teluk Ekas, Lombok Timur. 
Subani, W., 1987. Perikanan Udang Barong (Spiny Lobster) dan Prospek Masa Depannya. Bulletin Penelitian Perikanan Volume I (3). Pusat Penelitian dan Pengembangan Perikanan, Jakarta.
Subani, W. 1984. Studi Mengenai Pergantian Kulit Udang Barong (Spiny Lobster, Panulirus spp) Kaitannya dengan Hasil Tangkapan. Laporan Penelitian Perikanan Laut. 